\title{
Epizyotomi Sonrası Perineal Ağrının Tedavisinde Kullanılan Nonfarmokolojik Yöntemlerin Sistematik Açıdan İncelenmesi
}

\author{
The Systematic Analyze Them in Terms The Nonpharmacological Methods Used in The Treatment of Perineal Pain \\ After Episiotomy
}

\author{
Nilüfer TOK YANIK ${ }^{1}$, Gül ERTEM ${ }^{2}$
}

\begin{abstract}
ÖZ
Epizyotomi, bebeğin güvenli doğumunu sağlamak, perine tonüsünü korumak ve istenmeyen yırtıkları önlemek amacıyla yapılan insizyondur. Perineal ağrı, özellikle postpartum ilk 3 gün boyunca, hareket etme, idrar yapma ve defekasyon, emzirme gibi günlük aktiviteleri olumsuz etkilemektedir. $\mathrm{Bu}$ nedenle epizyotomiden kaynaklanan ağrı tedavi edilmelidir. Son yıllarda farmakolojik olmayan yöntemler ya tek başlarına ya da birlikte ağrıyı azaltmada etkili olmaktadırlar. Temel amaç ağrı tedavisinde analjezik kulla-nım oranını azaltarak yaşam kalitesini yükseltmektir. Bu çalışmalardan 2007- 2017 arasında olan özellikle non-farmakolojik yöntemlerin etkilerini inceleyen 17 çalışmaya ulaşılmıştır. Epizyotomi sonrası perineal ağrının giderilmesinde soğuk jel pedi ve buz paketi uygulamasının, düşük frekanslı Transkutan Elektriksel Sinir Stimülasyonu (TENS) ve yüksek frekanslı TENS'in, bilek-ayak akapunktur uygulamasının, lavanta-timolü ilave edilerek hazırlanan yıkama solüsyonunun, tarçın merhemi ve atkuyruğu merheminin etkili olduğu, Düşük Doz Lazer Tedavisi (DDLT)'nin, kulak akapunktur uygulamasının etkili olmadığg saptanmıştır. Lavanta yağı ile hazırlanan oturma banyosunun bir çalışmada etkili olduğu saptanırken diğer çalışmada etkili olmadığ 1 saptanmıştır. Epizyotomi sonrası perineal ağrının giderilmesinde en etkili yöntemlerin kanıt düzeyinde araştırılması, bu yöntemlerin kullanımı ile ilgili sağlık çalışanlarına danışmanlık yapılması önerilmektedir.
\end{abstract}

Anahtar Kelimeler: Epizyotomi, Perineal Ağrı, Nonfarmakolojik Yöntemler.

\begin{abstract}
Episiotomy is an incision, it is used for to ensure the safe delivery of the baby, to maintain perineal tonus and to prevent unwanted tears. Perineal pain is adversely affects daily activities such as movement, urination, defecation and breastfeeding especially in during the first 3 days postpartum. Therefore pain resulting from episiotomy should be treated. In recent years, non-pharmacological methods are effective in reducing the pain alone or together. The main objective is to improve the quality of life by reducing the rate of analgesic use in the treatment of pain. It has been reached 17 studies from these studies specifically examining the effects of non-pharmacological methods between 2007- 2017. Cold gel pad and ice pack application, low frequency Transkütan Electrical Nerve Stimulation (TENS) and high frequency TENS, Wrist-ankle acupuncture application, lavender-timol added washing solution, cinnamon ointment and horse-tail ointment is effective, low dose laser therapy (LLLT), ear acupuncture was found to be ineffective for the removal of perineal pain after episiotomy. The sitz bath with lavender oil prepared has been found to be effective in a study and not effective in the other study. It is recommended that to investigation of at the level of evidence about the most effective methods, advising advising health professionals about the use of methods.
\end{abstract}

Keywords: Episiotomy, Perineal Pain, Nonpharmacological Methods.

\footnotetext{
*I. Ulusal Kadın Hastalıkları ve Ana Çocuk Sağlı̆̆ Kongresi’ nde poster bildiri olarak sunulmuştur.

${ }^{1}$ Öğr. Gör., Doğum ve Kadın Hastalıkları Hemşireliği Anabilim Dalı, Akdeniz Üniversitesi Hemşirelik Fakültesi, nilufertokyanik@gmail.com, ORCID: 0000-0001-2345-6789

${ }^{2}$ Prof.Dr., Kadın Sağlığı ve Hastalıkları Hemşireliği Anabilim Dalı, Ege Üniversitesi Hemşirelik Fakültesi, ertemgul19@gmail.com, ORCID: 0000-0002-5853-3980

İletişim / Corresponding Author:

Nilüfer TOK YANIK

e-posta/e-mail:

nilufertokyanik@gmail.com

Gelis Tarihi / Received:

26.11.2018

Kabul Tarihi/Accepted: 


\section{GíRIŞ}

Epizyotomi, bebeğin güvenli doğumunu sağlamak, perine tonüsünü korumak ve istenmeyen yırtıkları önlemek amacıyla; bebek başının doğumu sırasında perinede bulbokavernöz kasina yapılan insizyondur. ${ }^{1,2}$ Yüzyılın ilk yarısından itibaren dünyada epizyotomi oranı artmıştır. $\mathrm{Bu}$ oranlar Amerika \%62,5, Avrupa \%30, İsveç \%9,7 olarak rapor edilmiştir. ${ }^{3}$ Türkiye'de epizyotomi uygulaması \%64 olarak belirtilmiştir. Ülkemizdeki tüm doğumların $\% 65^{\prime}$ inden ve primiparların ise $\% 90$ ' nından fazlasına epizyotomi uygulanmaktadır. ${ }^{4}$

Doğum sonrası dönemde epizyotomi yap1lan kadınlarda genellikle perineal ağrı görülmektedir. ${ }^{5}$ Perineal ağrının doğumdan sonraki ilk 24 saatte şiddetinin fazla olduğu, ve sonraki 48 saat süre içerisinde yavaş yavaş azaldığ bildirilmiştir. ${ }^{6}$ Epizyotomi nedeniyle ortaya çıkan perineal ağrı, özellikle postpartum ilk 3 gün boyunca kadının hareket etme, idrar ve defekasyon yapma, emzirme gibi günlük aktivitelerini olumsuz yönde etkilemektedir. ${ }^{7-9} \mathrm{Bu}$ nedenle epizyotomiden kaynaklanan perineal ağrının tedavi edilmesi gereklidir. $^{7,8}$

Nonfarmakolojik yöntemler, ilaç dıșı yöntemlerle ağrının azaltılması olarak tanımlanmaktadır. $\mathrm{Bu}$ yöntemlerin kullanılmasında temel amaçlardan birisi ağrı tedavisinde analjezik kullanım oranını azaltarak kadının yaşam kalitesini yükseltmektir. Nonfarmakolo- jik yöntemlerin avantajları arasında, analjeziklerin gösterdiği yan etkilerinin olmaması, kolay uygulanabilirliğinin olması ve ekonomik olması gelmektedir. ${ }^{10}$ Ağrı kontrolünde farmakolojik olmayan yöntemler arasında periferal tedaviler; soğuk-sicak uygulamalar, egzersiz, pozisyon verme, hareket kisitlamas1, dinlenme, akapunktur, hidroterapi, Transkutan Elektriksel Sinir Stimülasyonu (Transkütan Electrical Nerve Stimulation TENS), masaj ve dokunma, bilişsel davranışçı tedaviler; gevşeme, dikkati başka yöne çekme, dua etme, meditasyon, hipnoz, biyolojik geri besleme (biofeedback), davranış tedavisi ve diğer tedaviler, refleksoloji, aromaterapi, müzik terapi vb. girişimler yer almaktadır. ${ }^{11}$

Doğum sonrası farmakolojik ağrı kesici yöntemler non-steroid antiinflamatuar ilaçlar, oral analjezikler, lokal anestezikler ve opioidleri içerir. Ancak bu yöntemlerin, konstipasyon, gastrik rahatsızlık, anne sütüne ilacin geçişi ve uzun süreli kanama gibi ciddi yan etkileri vardır. Yüksek epizyotomi oranları göz önüne alındığında, hastalara vajinal doğum sonrasında kanıtlara dayalı perineal ağrı tedavi alternatifleri sunmak gerekmektedir. ${ }^{12}$

$\mathrm{Bu}$ sistematik derlemenin amacı, epizyotomi sonrası perineal ağrının tedavisinde nonfarmakolojik yöntemleri ve bu yöntemlerin ağrı üzerindeki etkilerini değerlendirmektir.

\section{YÖNTEM}

Sistematik derlemenin sorusunun çerçevesini belirlemede kisaca PICOS olarak adlandırılan bileşenler kullanılmaktadır. Derleme sorusu, katılımciları (P: population), müdahaleleri (I: interventions), karş1laştırma gruplarını (C: comparators), sonuçları (O: outcomes) ve araştırma desenlerini (S: study designs) açıkça tanımlamalıdır. ${ }^{13}$ Araştırma sorusunun bu bileşenleri aşağidaki şekilde gösterilmiştir.

Derleme Sorusu Epizyotomi sonrası ağrı tedavisinde en iyi nonfarmakolojik yöntemler nedir? Bu soru çerçevesinde, katılımcılar ola- rak; vajinal doğum sonrası epizyotomi uygulanmış pospartum dönemdeki kadınlar, müdahale olarak; nonfarmakolojik yöntemler, karş1laştırma grupları olarak müdahale uygulanan ve uygulanmayan kadınlar, müdahalelerin sonuçları ağrı kontrolü olarak belirlenmiştir. Araştırma deseni olarak; derleme yöntemi akış şeması (Şekil 1) yapılmıştır.

$\mathrm{Bu}$ sistematik derleme, "Episiotomy", "Perineal Pain", "Nonpharmacological Methods", "Treatment", "Epizyotomi", "Perineal Ağr1", "Nonfarmakolojik Yöntemler", "Tedavi" olarak ingilizce ve türkçe dilinde anah- 


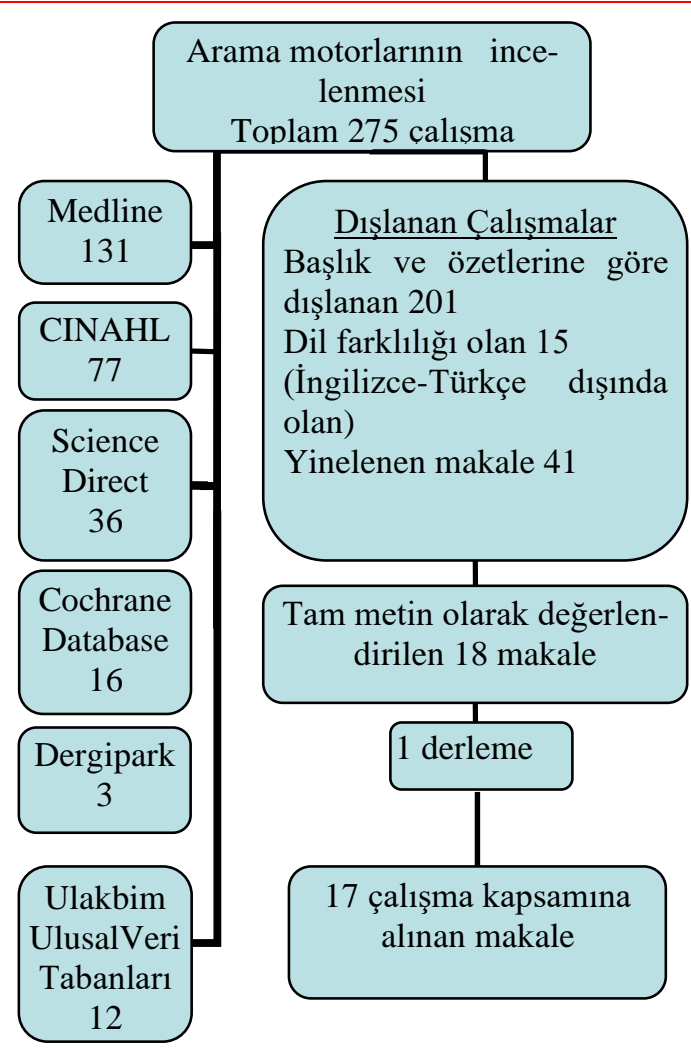

Şekil 1. Derleme Yöntemi Akış Şeması

\section{BULGULAR VE TARTIŞMA}

$\mathrm{Bu}$ sistematik derlemede, dokuzu randomize kontrollü çalışma, yedisi randomize kontrollü klinik çalışma, bir de pilot çalışma yer almıştır. Çalışmalardan elde edilen bulgular "Örneklem Büyüklüğü", "Yaş", "Parite" (toplam gebelik sayısı), Epizyotomi Çeşidi", "Kullanılan Ölçüm Araçları", "Nonfarmakolojik Yöntemler, Uygulama Özellikleri ve Ağrıyı Azaltmada Etkisi" başlıkları altında sunulmuştur (Tablo 1).

\section{Örneklem Büyüklüğü}

İncelemeye alınan çalışmaların örneklemini normal doğum yapan ve epizyotomisi olan kadınların oluşturduğu belirlenmiștir. Çalıșmaların örneklem sayılarına bakıldığında, en fazla örneklem sayısı $(n=250) \mathrm{Yu}-$ samran ve arkadaşları tarafindan yapılan çalışma, en az örneklem sayısı ile (n=30) Mahishale ve arkadaşları tarafından yapılan çalışmadır ${ }^{14,15}$ (Tablo 1).

Tablo 1. İncelemeye Dahil Edilen Çalışmaların Özellikleri

\begin{tabular}{|c|c|c|c|c|c|}
\hline $\begin{array}{l}\text { İncelenen } \\
\text { Çalışmalar }\end{array}$ & $\begin{array}{c}\text { Çalışmaların } \\
\text { Türü }\end{array}$ & Örneklem Grubu & $\begin{array}{c}\text { Nonfarmakolojik } \\
\text { Yöntem }\end{array}$ & $\begin{array}{c}\text { Nonfarmakolojik } \\
\text { Yöntemlerin Uygulanma } \\
\text { Özellikleri }\end{array}$ & $\begin{array}{l}\text { Kullanılan Yöntemin } \\
\text { Ağrıyı Azaltma ve İyi- } \\
\text { leşme Sürecine Etkisi }\end{array}$ \\
\hline $\begin{array}{r}\text { Yusamran } \\
\text { ve ark., } \\
\text { Tayland } \\
2007\end{array}$ & $\begin{array}{r}\text { Randomize } \\
\text { Kontrollü } \\
\text { Çalışma }\end{array}$ & $\begin{array}{r}\text { Girişim Grubu: } 125 \text { kad1- } \\
\text { na } \\
\text { soğuk jel ped } \\
\text { Kontrol Gurbu: } 125 \text { kad1- } \\
\text { na } \\
\text { jel ped }\end{array}$ & Soğuk jel ped & $\begin{array}{l}\text { Girişim: Doğumdan } \\
\text { sonra } 2 \text { saat boyunca her } 15 \\
\text { dk. da bir } \\
\text { Kontrol: Jel Paketi Pedi }\end{array}$ & $\begin{array}{l}\text { Soğuk jel pedin perine ağ- } \\
\text { rısını gidermede etkili ol- } \\
\text { duğu saptanmıştır. }\end{array}$ \\
\hline $\begin{array}{r}\text { Navvabi ve } \\
\text { ark., } \\
\text { İran } \\
2009\end{array}$ & $\begin{array}{r}\text { Randomize } \\
\text { Kontrollü } \\
\text { Çalışma }\end{array}$ & $\begin{array}{r}41 \text { kadına soğuk jel ped } \\
40 \text { kadına buz paketi } \\
40 \text { kadın kontrol grubu }\end{array}$ & $\begin{array}{r}\text { Soğuk jel ped } \\
\text { Buz paketi }\end{array}$ & $\begin{array}{l}\text { Girişim: } \\
\text { Doğum sonu } 4 \text { saat boyunca } \\
\text { (uygulama süresi belirtilme- } \\
\text { miş) } \\
\text { Kontrol: Tedavi yok }\end{array}$ & $\begin{array}{l}\text { Soğuk Jel pedin perineye } \\
\text { uygulanmasıyla, ağrının } \\
\text { şiddetini azalttığı kanıt- } \\
\text { lanmıştır. }\end{array}$ \\
\hline
\end{tabular}


GÜSBD 2020; 9(2): 195 - 208

Gümüşhane Üniversitesi Sağlık Bilimleri Dergis

Derleme Makalesi

GUJHS 2020; 9(2): 195 - 208

Gümüşhane University Journal of Health Sciences

Tablo 1. İncelemeye Dahil Edilen Çalışmaların Özellikleri (Devamı)

\begin{tabular}{|c|c|c|c|c|c|}
\hline $\begin{array}{l}\text { İncelenen } \\
\text { Çalışmalar }\end{array}$ & $\begin{array}{c}\text { Çalışmaların } \\
\text { Türü }\end{array}$ & Örneklem Grubu & $\begin{array}{c}\text { Nonfarmakolojik } \\
\text { Yöntem }\end{array}$ & $\begin{array}{c}\text { Nonfarmakolojik } \\
\text { Yöntemlerin Uygulanma } \\
\text { Özellikleri }\end{array}$ & $\begin{array}{c}\text { Kullanılan Yöntemin } \\
\text { Ağrıyı Azaltma ve İyileşme } \\
\text { Sürecine Etkisi }\end{array}$ \\
\hline $\begin{array}{r}\text { Leventhal } \\
\text { ve ark., } \\
\text { Brezilya } \\
2011\end{array}$ & $\begin{array}{r}\text { Randomize Kont- } \\
\text { rollü } \\
\text { Çalışma }\end{array}$ & $\begin{array}{r}38 \text { kadına buz paketi } \\
38 \text { kadına oda } \\
\text { sıcaklığında su paketi } \\
\text { (Plasebo) } \\
38 \text { kadın kontrol grubu }\end{array}$ & $\begin{array}{r}\text { Buz paketi } \\
\text { Oda sıcaklığında } \\
\text { su paketi }\end{array}$ & $\begin{array}{r}\text { Girişim: Doğum sonu } 2 \text { ila } \\
48 \text { saat arasında } 20 \mathrm{dk} \text {. tek } \\
\text { uygulama } \\
\text { Kontrol: Tedavi yok }\end{array}$ & $\begin{array}{r}\text { Buz paketi uygulanan kadın- } \\
\text { larda uygulanmayan kadınla- } \\
\text { ra (kontrol) göre perineal } \\
\text { ağrıda azalma saptanmış, } \\
\text { girişim grubu ile plasebo } \\
\text { grubu arasında bir fark sap- } \\
\text { tanmamıştır. } \\
20 \mathrm{dk} \text {. süre ile buz paketi } \\
\text { uygulanan kadınlarda peri- } \\
\text { neal ağrıda azalma olmuştur. }\end{array}$ \\
\hline
\end{tabular}

\begin{tabular}{|c|c|c|c|c|c|}
\hline $\begin{array}{r}\text { Oliveira ve } \\
\text { ark., } \\
\text { Brezilya } \\
2012\end{array}$ & $\begin{array}{r}\text { Randomize Klinik } \\
\text { Çalışma }\end{array}$ & $\begin{array}{r}38 \text { kadına } 10 \mathrm{dk} \text {. buz } \\
\text { paketi } \\
38 \text { kadına } 15 \mathrm{dk} \text {. buz } \\
\text { paketi } \\
38 \text { kadına } 20 \mathrm{dk} \text {. buz } \\
\text { paketi (Bu grup Leventhal } \\
\text { ve ark. }(2011) \text { çalışmasın- } \\
\text { da } 20 \text { dakika boyunca } \\
\text { perine üzerinde bir buz } \\
\text { torbası uygulanmış post- } \\
\text { natal kadınlardan oluş- } \\
\text { muştur. }\end{array}$ & Buz paketi & $\begin{array}{r}\text { Girişim: Doğum sonu } 2 \text { ile } \\
48 \text { saat arasında belirtilen } \\
\text { sürelerde tek uygulama }\end{array}$ & $\begin{array}{l}10 \mathrm{dk} ., 15 \mathrm{dk} \text {. ve } 20 \mathrm{dk} \text {. ol- } \\
\text { mak üzere üç farklı süreyle } \\
\text { uygulanan buz paketlerinin } \\
\text { ağrıyı azaltmada bir farklılık } \\
\text { olşturmadığı } 10 \mathrm{dk} \text {. ve } 15 \mathrm{dk} \text {. } \\
\text { süreli uygulamanın } 20 \mathrm{dk} \text {. } \\
\text { süreli uygulama kadar etkili } \\
\text { olduğu saptanmıştır. }\end{array}$ \\
\hline $\begin{array}{r}\text { Mahishale ve } \\
\text { ark., } \\
\text { Hindistan } \\
2013\end{array}$ & $\begin{array}{r}\text { Randomize Kont- } \\
\text { rollü } \\
\text { Çalışma }\end{array}$ & $\begin{array}{r}15 \text { kadına terapotik ult- } \\
\text { rason }+ \text { soğuk jel ped } \\
15 \text { kadına terapotik ult- } \\
\text { rason (Plasebo) }\end{array}$ & $\begin{array}{r}\text { Terapotik ultra- } \\
\text { son } \\
\text { Soğuk jel pedi }\end{array}$ & $\begin{array}{r}\text { Girişim: Terapotik ultrason } \\
\text { (3 gün boyunca günde iki } \\
\text { kez } 5 \mathrm{dk} .) \\
\text { soğuk jel pedi ( } 3 \text { gün } \\
\text { boyunca günde iki kez 10- } \\
15 \mathrm{dk} \text {. süre ile) } \\
\text { Plasebo: terapötik ultrason }\end{array}$ & $\begin{array}{r}\text { Terapötik ultrason ve soğuk } \\
\text { jel pedin perineal ağrının } \\
\text { azaltılmasında etkili olduğu } \\
\text { kanıtlanmıştır }\end{array}$ \\
\hline $\begin{array}{r}\text { Pitangui ve } \\
\text { ark., } \\
\text { Brezilya } \\
2012\end{array}$ & $\begin{array}{l}\text { Randomize Kont- } \\
\text { rollü Çalışma }\end{array}$ & $\begin{array}{r}20 \text { kadına Yüksek Fre- } \\
\text { kanslı TENS } \\
20 \text { kadın kontrol grubu }\end{array}$ & $\begin{array}{r}\text { Yüksek Frekanslı } \\
\text { TENS }\end{array}$ & $\begin{array}{r}\text { Girişim: Deriye epizyotomi } \\
\text { bölgesine paralel olarak yer- } \\
\text { leştirilmiş } 4 \text { adet silikon- } \\
\text { karbon elektrot ile } 60 \mathrm{dk} \text {. } \\
\text { süreyle Yüksek (100 Hz) } \\
\text { Frekansli TENS } \\
\text { Kontrol: Tedavi yok }\end{array}$ & $\begin{array}{r}\text { TENS kullanımı sonrasında } \\
\text { perineal ağrı şiddetinin } \\
\text { önemli ölçüde azaldığı sap- } \\
\text { tanmıştır. }\end{array}$ \\
\hline $\begin{array}{r}\text { Pitangui ve } \\
\text { ark., } \\
\text { Brezilya } \\
2014\end{array}$ & $\begin{array}{r}\text { Randomize Kont- } \\
\text { rollü, Çift Körlü } \\
\text { Klinik Çalışma }\end{array}$ & $\begin{array}{r}11 \text { kadına Yüksek Fre- } \\
\text { kanslı TENS } \\
12 \text { kadına Düşük Fre- } \\
\text { kanslı TENS } \\
10 \text { kadına Frekans ol- } \\
\text { madan TENS (Plasebo) }\end{array}$ & $\begin{array}{r}\text { Yüksek Frekans- } \\
\text { lı TENS } \\
\text { Düşük Frekansl1 } \\
\text { TENS }\end{array}$ & $\begin{array}{r}\text { Girişim: Deriye epizyotomi } \\
\text { bölgesine paralel olarak yer- } \\
\text { leştirilmiş } 4 \text { adet silikon- } \\
\text { karbon elektrot ile } 30 \text { dk. } \\
\text { süreyle Yüksek Frekanslı } \\
\text { (100 Hz) ve Düşük Frekans- } \\
11(5 \mathrm{~Hz}) \text { TENS } \\
\text { Plasebo Grubu Frekans ol- } \\
\text { madan 30dk. süreyle TENS }\end{array}$ & $\begin{array}{r}\text { Düşük frekanslı TENS ve } \\
\text { yüksek frekanslı TENS uy- } \\
\text { gulamasının ağrıyı rahatlat- } \\
\text { mada farklılık oluşturmadığı } \\
\text { saptanmıştır. }\end{array}$ \\
\hline $\begin{array}{r}\text { Santos ve } \\
\text { ark., } \\
\text { Brezilya } \\
2012 \mathrm{a}\end{array}$ & $\begin{array}{r}\text { Randomize Klinik } \\
\text { Çalışma; Pilot } \\
\text { Çalışma }\end{array}$ & $\begin{array}{r}26 \text { kadına Düşük Dozlu } \\
\text { Lazer Tedavisi } \\
26 \text { kadına ışınlama ol- } \\
\text { maksızın Düşük Dozlu } \\
\text { Lazer Tedavisi (Plase- } \\
\text { bo) }\end{array}$ & DDLT & $\begin{array}{r}\text { Girişim: Doğum sonu } 2 . \\
\text { Saate kadar, 20-24 saat arası } \\
\text { ve 40-48 saat arası olmak } \\
\text { üzere üç kez } 660 \text { nanometre } \\
\text { (nm) dalga boyunda DDLT } \\
\text { (kırmızı 1şı) } \\
\text { Plasebo: Işınlama olmaks1- } \\
\text { zın uygulama }\end{array}$ & $\begin{array}{r}\text { Lazer tedavisi uygulanan ve } \\
\text { uygulanmayan kadınlar ara- } \\
\text { sinda perineal ağrı açısından } \\
\text { fark bulunamamıştır. }\end{array}$ \\
\hline $\begin{array}{r}\text { Santos ve } \\
\text { ark., } \\
\text { Brezilya } \\
2012 b\end{array}$ & $\begin{array}{r}\text { Çift Körlü Ran- } \\
\text { domize Klinik } \\
\text { Çalışma }\end{array}$ & $\begin{array}{r}38 \text { kadına Düşük Dozlu } \\
\text { Lazer Tedavisi (kızı̈ö- } \\
\text { tesi lazer) } \\
38 \text { kadına Düşük Dozlu } \\
\text { Lazer Tedavisi (kırmızı } \\
\text { lazer) } \\
38 \text { kadına ışınlama ol- } \\
\text { maksızın lazer uygula- } \\
\text { ması }\end{array}$ & DDLT & $\begin{array}{r}\text { Girişim: DDLT } 780 \mathrm{~nm} \text { dal- } \\
\text { ga boyunda (kızılötesi lazer) } \\
\text { Girişim: DDLT } 660 \mathrm{~nm} \text { dal- } \\
\text { ga boyunda } \\
\text { (kırmızı lazer) } \\
\text { Plasebo: Işınlama olmaksı- } \\
\text { zın uygulama }\end{array}$ & $\begin{array}{l}\text { Lazer tedavisi uygulanan ve } \\
\text { uygulanmayan kadınlar ara- } \\
\text { sında perineal ağnı rahatla- } \\
\text { masında önemli fark olmadı- } \\
\text { ğ1 saptanmıştır. }\end{array}$ \\
\hline
\end{tabular}


GÜSBD 2020; 9(2): 195 - 208

Gümüșhane Üniversitesi Sağlık Bilimleri Dergisi

Derleme Makalesi

GUJHS 2020; 9(2): 195 - 208

Gümüşhane University Journal of Health Sciences

Tablo 1. İncelemeye Dahil Edilen Çalışmaların Özellikleri (Devamı)

\begin{tabular}{|c|c|c|c|}
\hline $\begin{array}{c}\text { İncele- } \\
\text { nen } \\
\text { Çalış- } \\
\text { malar }\end{array}$ & $\begin{array}{c}\text { Çalışmaların } \\
\text { Türü }\end{array}$ & Örneklem Grubu & $\begin{array}{l}\text { Nonfarmakolo- } \\
\text { jik Yöntem }\end{array}$ \\
\hline $\begin{array}{r}\text { Alvaren- } \\
\text { ga ve } \\
\text { ark., } \\
\text { Brezilya } \\
2017\end{array}$ & $\begin{array}{r}\text { Üç Körlü } \\
\text { Randomize } \\
\text { Kontrollü } \\
\text { Çalışma }\end{array}$ & $\begin{array}{r}29 \text { kadına } \\
\text { DDLT } \\
25 \text { kadın ışın- } \\
\text { lama olmaksızın } \\
\text { uygulama (Pla- } \\
\text { sebo) }\end{array}$ & $\begin{array}{r}\text { Düşük Dozlu } \\
\text { Lazer Tedavisi } \\
\text { (DDLT) }\end{array}$ \\
\hline $\begin{array}{r}\text { Kindberg } \\
\text { ve ark., } \\
\text { Danimarka } \\
2008\end{array}$ & $\begin{array}{r}\text { Randomize } \\
\text { Kontrollü Ça- } \\
\text { lışma }\end{array}$ & $\begin{array}{r}102 \text { kadına ku- } \\
\text { lak akapunktur } \\
105 \text { kadına lo- } \\
\text { kal anestezi }\end{array}$ & Kulak akapunktur \\
\hline $\begin{array}{r}\text { Marra ve } \\
\text { ark., } \\
\text { İtalya } \\
2011\end{array}$ & Pilot Çalışma & $\begin{array}{r}21 \text { kadına Bi- } \\
\text { lek-ayak bileği } \\
\text { akupunkturu } \\
21 \text { kadın kontrol } \\
\text { grubu }\end{array}$ & $\begin{array}{r}\text { Bilek-ayak bileği } \\
\text { akupunkturu }\end{array}$ \\
\hline $\begin{array}{r}\text { Vakilian ve } \\
\text { ark., } \\
\text { İran } \\
2011\end{array}$ & $\begin{array}{r}\text { Randomize } \\
\text { Kontrollü } \\
\text { Klinik Çalışma }\end{array}$ & $\begin{array}{r}60 \text { kadına la- } \\
\text { vanta yağı } \\
60 \text { kadina Po- } \\
\text { vidon-iyot } \\
\text { (Kontrol Gru- } \\
\text { bu) }\end{array}$ & $\begin{array}{r}\text { Lavanta yağı ile } \\
\text { hazırlanan oturma } \\
\text { banyosu }\end{array}$ \\
\hline $\begin{array}{r}\text { Sheikhan } \\
\text { ve ark., } \\
\text { İran } \\
2012\end{array}$ & $\begin{array}{c}\text { Randomize } \\
\text { Kontrollü } \\
\text { Klinik Çalışma }\end{array}$ & $\begin{array}{r}30 \text { kadına la- } \\
\text { vanta yağı } \\
30 \text { kadına } \\
\% 10 \text { 'luk Beta- } \\
\text { dine (Kontrol } \\
\text { Grubu) }\end{array}$ & $\begin{array}{r}\text { Lavanta yağı ile } \\
\text { hazırlanan oturma } \\
\text { banyosu }\end{array}$ \\
\hline $\begin{array}{r}\text { Marzouk } \\
\text { ve ark., } \\
\text { Misır } \\
2014\end{array}$ & $\begin{array}{c}\text { Tek Körlü } \\
\text { Randomize } \\
\text { Klinik Ça- } \\
\text { lişma }\end{array}$ & $\begin{array}{r}60 \text { kadına la- } \\
\text { vanta-timol } \\
\text { yağ1 } \\
60 \text { kadına } \% 0.9 \\
\text { salin }\end{array}$ & $\begin{array}{l}\text { Lavanta-timol } \\
\text { yağı ile hazırla- } \\
\text { nan perine y1- } \\
\text { kama solüsyonu }\end{array}$ \\
\hline
\end{tabular}

Nonfarmakolojik
Yöntemlerin Uygulanma Özellikleri

Girişim: Doğumsonu 6-10 saat arası, 20-

24 saat aras1 ve 40-48 saat arası olmak

üzere üç seans $780 \mathrm{~nm}$ dalga boyunda

DDLT (lazer çeşidi belirtilmemiş)

uygulaması Plasebo: Işınlama olmaksızın uygulama

Kontrol: Lidokain $10 \mathrm{mg} / \mathrm{ml}$ dikiş atma

işlrminden 5 dakika sonra doğrudan yaranın içine uygulanmıştır.

Girişim: bilek-ayak bileği akupunkturu

Kontrol: Akapunktur yok

(n)

Kullanılan Yöntemin
Ağrıyı Azaltma ve İyileş-
me Sürecine Etkisi

Lazer tedavisi uygulanan

ve uygulanmayan iki grup

arasında ağrı skorları açı-

sindan

anlamlı fark saptanmamış-

Kulak akapunkturun ağrıyı

rahatlatmada lokal aneste-

ziye göre daha az etkili olduğu saptanmıștır.

Sağ ayak bileği akupunktu-

run perineal ağriyı azalt-

mada etkili olduğu saptan-

miştır.

Girişim:

$4 \mathrm{~L}$ su içerisine 5-7 damla temel lavanta yağı günde iki kez olmak üzere 10 gün süre ile oturma banyosu olarak kullanıl-

mıştır.

Kontrol: 4 L su içerisine 5-7 damla Povidon-iyot günde iki kez olmak üzere 10 gün süre ile oturma banyosu olarak kullanılmıştır.

Girişim: 5 L su içerisine $25 \mathrm{~mL}$ Lavanta yağı özü konularak hazırlanan oturma banyosu 5 gün boyunca günde iki kez 30 dakika olmak üzere uygulanmıştır Kontrol: 4 L su içerisine 10 mL \%10'luk Betadine konularak hazırlanan oturma banyosu 5 gün boyunca günde iki kez 30 dakika olmak üzere uygulanmıştır. Girişim: 4 L sıcak musluk suyuna 7 damla daha önce hazırlanmış lavanta-timolü ilave edilerek hazırlanan çözelti 250 mL'lik sıkma şişesi kullanılarak 7 gün boyunca günde iki kez insizyon bölgesini yıkamaları ardından perine bölgesini önden arkaya doğru kurutulmaları istenmiştir.

Plasebo: 4 L sicak musluk suyuna $10 \mathrm{~mL}$ salin $(\% 0.9)$ ilave edilerek hazırlanan çözelti 250 mL'lik sıkma şişesi kullanılarak

7 gün boyunca günde iki kez insizyon bölgesini yıkamaları ardından perine bölgesini önden arkaya doğru kurutulmaları istenmiştir.
Doğum sonrası ağrı skorları açısından gruplar arasında fark saptanmamıştır.

Epizyotomiden 4 saat ve 5 gün sonrası lavanta yağının ağrı şiddetini azaltmada etkili olduğu saptanmış, 12 saat sonrasında ağrı skorları açısından gruplar arasında fark saptanmamıştır.

Postpartum 7. günde girişim grubundaki ağrı şiddetinin plasebo grubuna göre azaldığ saptanmıştır.

\begin{tabular}{rcrr}
\hline Moham- & Randomize & 72 kadına Cin- & Cinnamon (Tar- \\
madi ve & Plasebo- & namon (Tarçın) & çın) Merhemi \\
ark., & Kontrollü & Merhemi & \\
İran & Çalışma & 72 kadına tarçın & \\
2014 & & özü olmayan & \\
& & krem (Plasebo) &
\end{tabular}

$\begin{array}{rr}\text { Girişim: Epizyotomi onarımı } & \text { Tarçın merhemi uygulama- } \\ \text { tamamlandıktan 1 saat uygulamaya } & \begin{array}{r}\text { sının doğumdan sonraki 10 } \\ \text { gün içinde ağrı şiddetini } \\ \text { başlanılmıştır. İnsizyon bölgesine yakla- } \\ \text { ş1k 2mL merhem sürdükten 1-2 dakika }\end{array} \\ \text { sonra hijyenik kadın bağı takılarak uygu- } \\ \text { lama yapmaları istenmiştir. Bu uygula- }\end{array}$


Tablo 1. İncelemeye Dahil Edilen Çalışmaların Özellikleri (Devamı)

\begin{tabular}{|c|c|c|c|c|c|}
\hline $\begin{array}{l}\text { Íncelenen } \\
\text { Çalışmalar }\end{array}$ & $\begin{array}{c}\text { Çalışmaların } \\
\text { Türüi }\end{array}$ & Örneklem Grubu & $\begin{array}{c}\text { Nonfarmakolojik } \\
\text { Yöntem }\end{array}$ & $\begin{array}{l}\text { Nonfarmakolojik } \\
\text { Yöntemlerin Uygulanma Özel- } \\
\text { likleri }\end{array}$ & $\begin{array}{c}\text { Kullanılan Yöntemin } \\
\text { Ağrıyı Azaltma ve } \\
\text { İyileşme Sürecine Et- } \\
\text { kisi } \\
\end{array}$ \\
\hline $\begin{array}{r}\text { Asgharikhatooni } \\
\text { ve ark., } \\
\text { İran } \\
2015\end{array}$ & $\begin{array}{r}\text { Randomize } \\
\text { Plasebo- } \\
\text { Kontrollü } \\
\text { Çalışma }\end{array}$ & $\begin{array}{r}54 \text { kadına Equise- } \\
\text { tum arvense (At } \\
\text { Kuyruğu) Merhe- } \\
\text { mi } \\
54 \text { kadına vazel- } \\
\text { in+bir kaç } \\
\text { damla at kuyruğu } \\
\text { ekstresi }\end{array}$ & $\begin{array}{r}\text { Equisetum arvense } \\
\text { (At Kuyruğu) } \\
\text { Merhemi }\end{array}$ & $\begin{array}{r}\text { Girişim: İnsizyon bölgesini } \\
\text { merhem sürdükten 1-2 dakika } \\
\text { sonra hijyenik kadın bağı takı- } \\
\text { larak uygulama yapmaları is- } \\
\text { tenmiştir. } \\
\text { Bu uygulamayı günde iki kez } \\
12 \pm 2 \text { saat aralıklarla } 10 \text { gün } \\
\text { süreyle gerçekleştirmeleri is- } \\
\text { tenmiştir. } \\
\text { Plasebo: Vazelin ve birkaç } \\
\text { damla at kuyruğu ekstresi kul- } \\
\text { lanılarak hazırlanan steril pla- } \\
\text { sebo merhemi girişim } \\
\text { grubundaki gibi uygulanmıştır. }\end{array}$ & $\begin{array}{r}\text { At Kuyruğu merhemi } \\
\text { uygulamasının doğum- } \\
\text { dan sonraki } 10 \text { gün için- } \\
\text { de ağrı şiddetini azalt- } \\
\text { mada etkili olduğu sap- } \\
\text { tanmıştır. }\end{array}$ \\
\hline
\end{tabular}

\section{Yaş}

Yara iyileşmesini olumsuz yönde etkileyen önemli bir faktörde yaş artışıdır. ${ }^{2}$ Derlemede, en düşük yaş sınırı Navvabi ve arkadaşlarının yaptığı çalışmada 16 , en yüksek yaş sınırı Yasumran ve arkadaşlarının yaptığı çalışmada 42 olarak saptanmıştır. ${ }^{14,16}$ Dünyada doğurganlık yaş grubu 15-49 olarak belirlenmiştir, incelediğimiz çalışmalarda ortalama yaşların 15-49 yaş grubu arasında olduğu görülmektedir. ${ }^{17}$ Sistematik inceleme kapsamındaki kadınların yaş ortalaması en düşük 20,5 , en yüksek $29 \pm 5,4$ olarak saptanmıştır. ${ }^{14,18}$ Kartal ve arkadaşlarının çalışmasında epizyotomi yapılan kadınların ortalama yaşı $24,05 \pm 2,4$, Kalis ve arkadaşlarının çalışmasinda 27,25 $\pm 3,91$ Keramat ve Khosravi'nin çalışmasında 25,79, Karbanova'nın çalışmasında ortalama yaş 28,1 olarak saptanmış, bu sonuçlar derlemedeki sonuçlarla benzerlik göstermekle birlikte yaş ortalamalarının düşük olduğu görülmüştür. ${ }^{19-23} \mathrm{Bu}$ sonuçlar, epizyotomi uygulamasının genç annelerde daha sıklıkla yapıldığını göstermektedir.

\section{Parite}

Parite, doğum şekli, doğum deneyimi, perineal travma derecesi ve neonatal doğum ağırlığı gibi perineal ağrının şiddetini etkileyen birkaç faktör olabilir. Epizyotomi uygulamasının primiparlarda multiparlara göre daha fazla kullanıldığı, perineal ağrının primiparlar arasında daha yaygın olduğu belirtilmiştir. ${ }^{24,25}$ Ülkemizde yapılan bir çalışmada, primipar gebelerin \%96,72'sine, multipar gebelerin ise \%51,85'ine epizyotomi uygulandiğ 1 saptanmıştır. ${ }^{25}$ Latin Amerika'da primipar kadınlarda epizyotomi yapılma oranının incelendiği bir çalışmada, 91 hastanede $\% 80$ 'den fazla, 69 hastanede \%90'dan daha fazla epizyotomi uygulandığ saptanmıştır. $^{26}$ Yapılan başka bir çalışmada ise primipar kadınların \%81,7'sine epizyotomi uygulandığ ve bu kadınlarda epizyotomi uygulanmamış kadınlara göre daha fazla perineal ağrı yaşandığı saptanmıştır. ${ }^{9}$ İncelediğimiz çalışmalardan sekizinde primipar, dördünde ise nullipar kadınlar çalışmaya alınmıştır (Tablo 2). Daha fazla ağrı yaşamaları nedeniyle primipar ve nullipar kadınların çalışmalarda daha fazla ele alındığı görülmektedir. 
Tablo 2. Tanımlayıcı Özellikler ve Ağrı Skorları

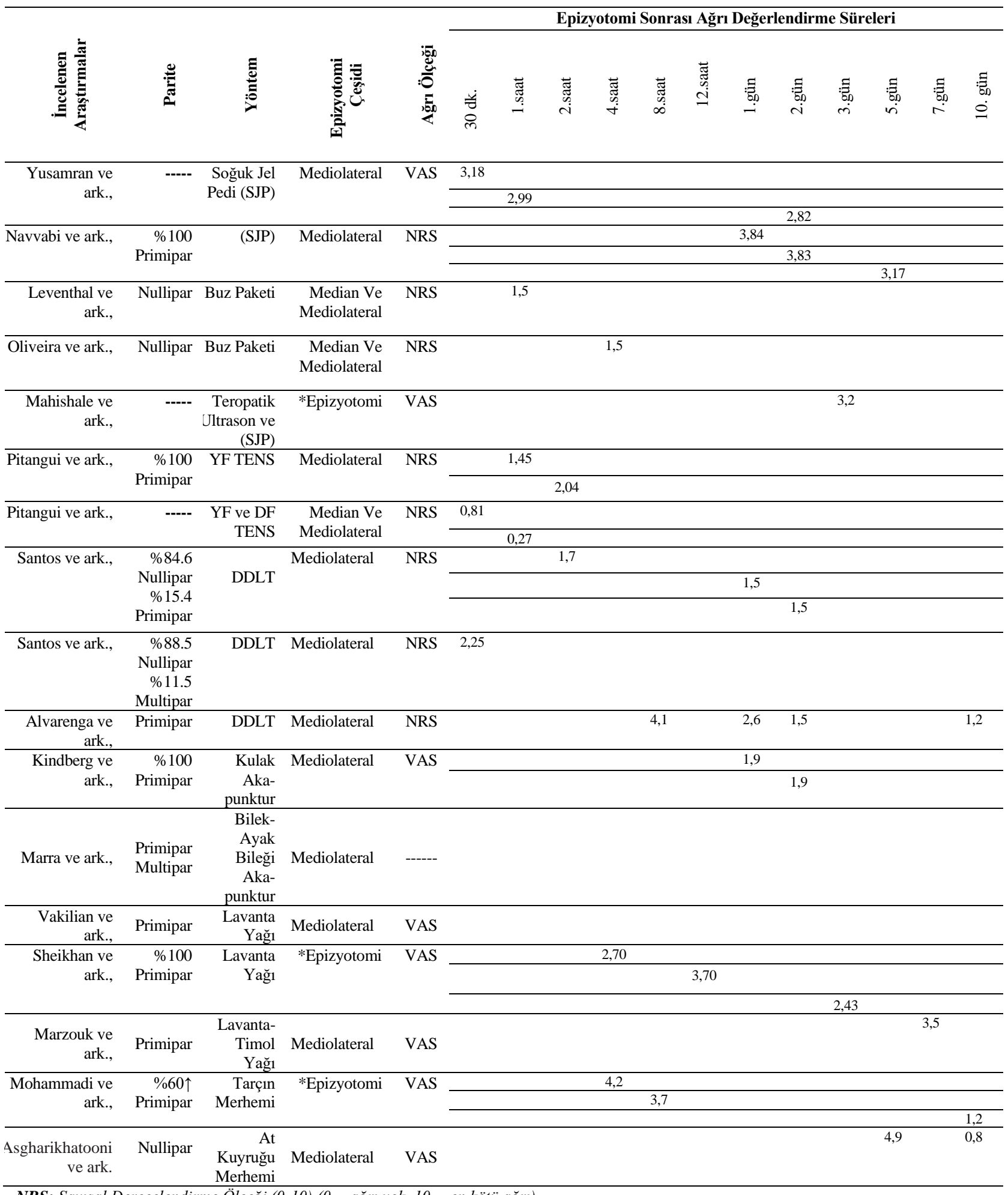

NRS: Saylsal Derecelendirme Ölçeği $(0-10)(0=$ ăgr yok, $10=$ en kötü ăgrl)

VAS: Vizuel Analog Skala (0-10)

*Epizyotomi çeşidi belirtilmemiş

\section{Epizyotomi Çeşidi}

Epizyotominin günümüzde halen kullanılan median ve mediolateral olmak üzere iki majör tipi mevcuttur. ${ }^{27}$ Birleşmiş milletlere bağl1 birçok ülkede median epizyotomi tercih edilmektedir. Median yapilan epizyotomi sonrası ağrının daha az görüldüğü belirtilmekte bunun nedenin ise median epizyotominin mediolateral ve lateral epizyotomiye göre daha az kanama, daha az ağrı yaşanması ve daha hızlı iyileşmesi olarak belirtilmiştir. ${ }^{28}$ Yapılan bir çalışmada, mediolateral epizyotomi uygulanan kadınlarda median 
epizyotomi uygulanan kadınlara göre daha fazla postpartum ağrı ve disparoni saptanmıştır. ${ }^{29}$ Prospektif gözlemsel bir çalışmada postpartum 3. ayda ağrı skorları açısından median ve mediolateral epizyotomi arasında fark saptanmamıştır. ${ }^{30} \mathrm{Bu}$ sistematik derlemede onbir çalışmada mediolateral, üç çalışmada median ve mediolateral, üç çalışmada ise epizyotomi uygulanmış fakat uygulanan epizyotomi çeşidi belirtilmemiştir. $\mathrm{Bu}$ sonuçlar mediolateral epizyotomi kullanımının daha yaygın olduğunu göstermektedir (Tablo 2).

\section{Kullanılan Ölçüm Araçları}

Ağrının izlenmesinde sayısal değerlendirme skalaları çok kullanılması sebebiyle kanıtlanmış oldukça değerli yöntemlerdir. Bu yöntemlerden biri olan Görsel Analog skala (Vizuel Analog Skala VAS) sayısal olarak ölçülemeyen değerleri sayısal hale çevirmede kullanılır. Sayısal Değerlendirme Skalası (Numerical Rating Scale NRS) ağrının izlenmesinde çok kullanılması nedeni ile değerli bir yöntemdir. Sayısal Değerlendirme Skalasında ağrının yokluğu (0) ile başlayıp dayanılmaz ağrı (10 ya da 100) düzeyine varır. ${ }^{31}$ İncelememize alınan çalışmalarda ağrı değerlendirme yöntemleri olarak sekiz çalışmada VAS ve diğer sekiz çalışmada NRS ölçekleri kullanılmıştır. Çalışmaların on altısında, 0-10 arası puanlama yapılmış, en düşük ağrı skorları buz baketi uygulaması 1. ve 4 . saatte 1,5 , yüksek frekanslı TENS uygulaması 1. saatte 1,45 yüksek frekanslı TENS ve düşük frekanslı TENS uygulaması 0,27 , lavanta yağ uygulaması 4. saatte 2,70, lavanta-timol yağ1 uygulaması 7 . günde 3,5 , tarçın merhemi uygulamas1 10. günde 1,2 , at kuyruğu merhemi uygulaması 10. günde 0,8 olarak saptanmıştır (Tablo 2). ${ }^{18,32-38}$

\section{Nonfarmakolojik Yöntemler, Uygulama Özellikleri ve Ağrıyı Azaltmada Etkisi}

\section{- Soğuk Uygulama}

Gelişmiş ülkelerde perineal ağrı kontrolü için soğuk uygulama kullanılmıştır. Soğuk uygulamanın amacı, inflamasyon süresini azaltmak ve yumuşak dokunun iyileşmesine katk1 sağlayarak hastaların normal aktivitele- rine daha hızlı dönmelerine yardımcı olmaktir. $^{39}$

Sistematik derlemede, lokal soğuk uygulamanın, yara iyileşmesini olumsuz etkilemeden, perineal ağrıyı, şişmeyi ve morarmayı azaltmada etkili olduğunu göstermiştir. ${ }^{40}$ Doğumdan sonra 24 saat içinde perineye buz paketleri uygulaması ağrının acil olarak semptomatik rahatlatılması için kullanılan bir yöntemdir. ${ }^{12}$ Brezilya'da "Vajinal doğum sonrası perineal ağrı giderilmesinde farmakolojik ve nonfarmakolojik tedavi türlerini tanımlamak için yapılan çalışmanın sonucunda, 130 hastanın \%98,5 ilaç kullandıklarını ve bunların \%62,3 aynı zamanda buz paketi, s1cak oturma banyosu ve sicak kompres gibi ilaç dışı tedavileri kullandıkları saptanmıştir. $^{41}$

Yusamran ve arkadaşları, soğuk jel pedini doğumdan sonraki 2 saat süreçte her $15 \mathrm{dk}$. bir uygulamışlardır. ${ }^{14}$ Navvabi ve arkadaşları, epizyotomi sonrası 4 saatlik süreçte soğuk jel pedi ve buz paketi uygulamış, çalışmada uygulama süreleri hakkında bilgi verilmemiştir. ${ }^{16}$ Leventhal ve arkadaşları, doğum sonu 2 ile 48 saat ararsında 20 dakika süreyle buz paketi ve oda sıcaklığında su paketi bir kez uygulamıştır. ${ }^{32}$ Oliveira ve arkadaşları, buz paketini $10 \mathrm{dk} ., 15 \mathrm{dk}$. ve $20 \mathrm{dk}$. sürelerle uygulamışlardır. ${ }^{33}$ Mahishale ve arkadaşları, kontrol grubuna 3 gün süreyle günde $2 \mathrm{kez} 5$ dakika süreyle töropatik ultrason, deney grubuna ise 3 gün, günde iki kez 10-15 dk. süreyle töropatik ultrason ve soğuk jel ped uygulamışlardır. ${ }^{15}$

Perineye $20 \mathrm{dk}$. süreli buz paketi uygulamasının ağrıyı azaltmada etkili olduğu, 10 $\mathrm{dk}$. ve $15 \mathrm{dk}$. buz paketi uygulamasının 20 dk. uygulama kadar etkili olduğu saptanmıştır. ${ }^{32,33}$ Yapılan bir çalışmada $20 \mathrm{dk}$. süreyle uygulanan buz paketi uygulamasının perineal ağrının şiddetini azaltmada etkili olduğu saptanmıştır. ${ }^{42}$ Perineye doğumdan sonra 24 saat içinde $20 \mathrm{dk}$. süre ile bir kez uygulanan buz paketi uygulamasından $20 \mathrm{dk}$ ve 1 saat sonrasında ağrı şiddetinde azalma olduğu tespit edilmiştir. ${ }^{43} \mathrm{Bu}$ sonuçlar $20 \mathrm{dk}$. süreli buz paketi uygulamasının perineal ağrıyı azaltmada daha etkili olduğunu düşündürmektedir. 
Soğuk jel pedin perine ağrısını gidermede buz paketine göre daha etkili olduğu bildirilmiştir. ${ }^{14,16}$ Yapılan bir çalışmada, soğuk jel pedin, buz paketine göre ağrıyı azaltmada daha etkili olduğu bulunmuştur. ${ }^{44,45}$ Benzer çalışmalarda, soğuk-jel paketi uygulamasının perineal ağrının giderilmesinde etkili olduğu saptanmıştır. ${ }^{46-48}$ Tüm bu sonuçlar, sistematik derleme bulgularımız ile uyum göstermekle birlikte, soğuk-jel pedin doğumdan sonra perineal ağrının giderilmesi için etkili bir uygulama olduğu söylenebilir.

\section{- TENS}

TENS, kadına kendi bakımı üzerinde kontrol duygusu veren güvenli bir ağrı giderme yöntemidir. ${ }^{49}$ TENS, cildin üzerine yerleştirilen yüzey elektrotları aracılığıyla, darbeli kare dalga akımının, ağrı kontrolü için periferik sinir liflerine uygulanmasıdır. TENS noninvazif ve bağımlılık yapıcı olmayan bir tedavidir. TENS anestezi veya sinir bloğu üretmez. ${ }^{50}$ Pitangui ve arkadaşları, dört adet silikon-karbon elektrotu deriye epizyotomi bölgesine paralel olarak yerleştirilmiş, $60 \mathrm{dk}$. süreyle $100 \mathrm{Hertz}(\mathrm{Hz})$ Yüksek Frekanslı TENS uygulamışlardır. Pitangui ve arkadaşları başka bir çalışmada, elektrotları epizyotomi bölgesine yakın paralel olarak yerleştirmiş, bir gruba 30 dakika süreyle yüksek frekanslı TENS $(100 \mathrm{~Hz})$, diğer gruba düşük frekanslı TENS $(5 \mathrm{~Hz})$ ve plasebo grubuna frekans olmadan TENS uygulamışlardır. Düşük frekanslı TENS ve yüksek frekanslı TENS uygulamasının perineal ağrıyı rahatlatmada farklılık oluşturmadığı, fakat Yüksek Frekanslı TENS kullanımının hemen ardından ve $60 \mathrm{dk}$. sonrasında perineal ağrı şiddetinin önemli ölçüde azaldığı saptanmıştır ${ }^{18,34}$ Benzer çalışmalarda, TENS uygulamasının primer dismenorenin tedavisinde kullanıldığ 1 ve doğum ağrisında azalma sağladığ 1 saptanmıştır. ${ }^{51,52}$ TENS' in diz ağriları ve osteoartriti olan bireylerin ağrıları için güvenli ve uygulanabilir bir yöntem olduğu belirtilmiştir. ${ }^{53,54}$

\section{-DDLT}

Düşük Doz Lazer Tedavisi (DDLT), kollajen sentezi ve sinir rejenerasyonunu uyarır, anormal hormonal fonksiyonları düzenler, endorfin salınımını uyarır ve ağrıyı azaltır. ${ }^{55,56}$ DDLT'nin dokular üzerinde uyarıcı ve yeniden düzenleyici, iltahap giderici ve ağrı kesici etkileri bulunmaktadır. ${ }^{57}$ DDLT, postoperatif ağrıyı gidermede ilaç dışı bir yöntem olarak önerilmektedir. ${ }^{58}$

Santos ve arkadaşları, postpartum 2 saat 20 ve 24 saat aras1 ve 40 ile 48 saat aras1 epizyotomi sonrası sütur üzerine doğrudan üç seans DDLT uygulamışlardır, ${ }^{8}$ Santos ve arkadaşları diğer çalışmalarında epizyotomi sonras1 6-56 saat arasında tek seans doğrudan infrared ve kırmızı lazer içerikli DDLT uygulamışlardır. ${ }^{58}$ Alvarenga ve arkadaşları, postpartum 6-10 saat aras1, 20-24 saat aras1 ve 40-48 saat arası olmak üzere üç seans DDLT uygulamışlardır. ${ }^{59}$

Her üç çalışmada da DDLT uygulanan ve uygulanmayan kadınlar arasında perineal ağrı rahatlamasında önemli fark olmadığı saptanmıştır. ${ }^{8,54,55}$ Yapılan çalışmalarda, postpartum bakımda DDLT'nin perineal iyileşmeyi artırmak için tamamlayıcı bir uygulama olarak kullanılabileceği önerilmektedir. ${ }^{59,60}$

Yapılan metaanaliz çalışmasında, DDLT'nin doku onarımı ve ağrının giderilmesinde oldukça etkili bir terapötik yaklaşım olduğu kanıtlanmıştır. ${ }^{61}$ Yumuşak doku hasarından kaynaklanan akut ağrıda, akut boyun ağrısında DDLT'nin etkili olduğu saptanmıştir. $^{62,63}$

\section{-Akupunktur}

Akupunktur, ağrının tedavisi için alternatif veya tamamlayıcı bir tedavi olarak giderek daha fazla kullanılmaktadır. ${ }^{64}$ Doğum ağrısını azaltmak amaciyla el, ayak ve kulaktaki akupunktur noktaları kullanılmaktadır. ${ }^{65}$ Akupunkturun doğumdaki ağrı deneyimini azalttığ gösterilmiştir. $^{66}$

Kindberg ve arkadaşları, epizyotomi dikişinden $5 \mathrm{dk}$. sonra, direk yara içerisine 10 miligram/mililitre $(\mathrm{mg} / \mathrm{mL})$ Lidokain ve kulak alkapunkturu uygulamışlar perineal ağrıyı gidermede kulak akapunkturunun lokal anesteziye göre daha az etkili olduğunu tespit etmişlerdir. ${ }^{67}$ Marra ve arkadaşlarının çalışmasında bilek-ayak bileğine akuapunktur uygulamasının perineal ağrıyı azaltmada etkili olduğu saptanmıştır. ${ }^{68}$ Yapılan bir çalışmada, 
total kalça cerrahisinden sonra kulak akupunkturunun postoperatif analjezik gereksinimini azaltmak için kullanılabileceği saptanmıştır. ${ }^{69}$ Yapılan diğer bir çalışmada bilekayak bileği akapunkturunun primer dismenoresi olan genç kadınlarda etkili olduğu belirtilmiştir. ${ }^{70}$ Metaanaliz sonucuna göre, bilekayak bileği akupunkturunun hastalarda ağr1nın hafiflemesine yardımcı olduğunu ve oldukça güvenli bir terapi olduğunu kanıtlamıştir. $^{71}$

\section{- Aromaterapi}

Aromaterapi uçucu bitkisel kaynaklardan konsantre edilmiş yağlar ile masaj, kompres, buhar ve banyo yoluyla uygulanan terapötik tedavi şeklidir. ${ }^{72}$ Günümüzde bitkilerden elde edilen yağların yağların farmakolojik, fizyolojik ve psikolojik etkileri bilinmemektedir. Literatürde yağların içeriğindeki bileşenlerin, beyin sapındaki dopamin, endorfin, noradrenalin ve seratonin gibi maddelerin salınımına katkı sağladığı ve böylelikle analjezik etkisinin oluştuğu vurgulanmaktadır. Lavanta yağ1, analjezik, antidepresan ve sedatif etkiye sahiptir. ${ }^{50}$ Tarçın, çok uzun yıllardan beri biyoaktif bir baharat türü olarak kullanılmaktadır. Son dönemde yapılan çalışmalarda tarçının; güçlü antioksidan, antiinflamatuar, vazodilatör, antitrombotik, antiülseratif, antialerjik ve antibakteriyel özelliklere sahip olduğu gösterilmiștir. $^{73}$

Vakilian ve arkadaşlarının çalışmasında, girişim grubuna 4 Litre (L) su içerisine 5-7 damla lavanta yağı eklenmiş, günde iki kez olmak üzere 10 gün süre ile kontrol grubuna $4 \mathrm{~L}$ su içerisine 5-7 damla povidon-iyot eklenerek günde iki kez olmak üzere 10 gün süre ile oturma banyosu uygulanmış, perineal ağrı skorları açısından iki grup arasında fark saptanmamıştır. ${ }^{74}$

Sheikhan ve arkadaşlarının yaptığ çalışmada, girişim grubuna $5 \mathrm{~L}$ su içerisine $25 \mathrm{~mL}$ lavanta yağ özü konularak hazırlanan oturma banyosu 5 gün boyunca günde iki kez 30 dakika, kontrol grubuna $4 \mathrm{~L}$ su içerisine $10 \mathrm{~mL}$ $\% 10$ 'luk betadine konularak hazırlanan oturma banyosu 5 gün boyunca günde iki kez $30 \mathrm{dk}$. olmak üzere uygulanmıştır. Epizyotomiden 4 saat ve 5 gün sonrası lavanta yağı ile hazılanan oturma banyosunun perinal ağr1 şiddetini azaltmada etkili olduğu saptanmıştır. ${ }^{35}$ Marzouk ve arkadaşlarının çalışmasında, 4 L sicak musluk suyuna 7 damla lavantatimolü ilave edilerek $250 \mathrm{~mL}$ 'lik sıkma şişesine hazırlanan çözelti epizyotomi uygulanan kadınlara verilmiş, 7 gün boyunca günde iki kez olmak üzere perine bölgesini bu çözelti ile yıkamaları ardından önden arkaya doğru kurutmaları istenmiştir. Plasebo grubuna $4 \mathrm{~L}$ sicak musluk suyuna 7 damla $10 \mathrm{ml}$ Salin $(\% 0,9)$ ilave edilerek $250 \mathrm{~mL}$ 'lik sıkma şişesine hazırlanan çözeltiyi aynı şekilde uygulamaları istenmiştir. Çalışma sonucunda, postpartum 7. günde girişim grubundaki ağnı şiddetinin plasebo grubuna göre azaldığ 1 saptanmıştır. ${ }^{36}$ Lavanta yağı banyosunun kullanıldığı benzer bir çalışmada da, girişim grubunda ağrı düzeyinin kontrol grubuna göre belirgin bir şekilde azalma olduğu görülmüştür. $^{75}$

Karabulutun çalışmasında doğum sırasında aromaterapi uygulamasının kadının doğum ağrısına tahammülünü arttırdığı saptanmıştır. ${ }^{76}$ Aromaterapinin sezaryen sonrası a ğrı üzerine etkisi değerlendiren bir çalışmada lavanta yağı özü buharının sezaryen sonrası ağrının tedavisinin bir parçası olarak kullanılabileceği ancak tek ağrı tedavisi olamayacağ 1 saptanmıştır. ${ }^{77}$

\section{- Bitkisel Tedavi}

Bitkisel tedavi, tıbbi amaçlar için herhangi bir bitkinin tohumlarının, meyvelerinin, köklerinin, yapraklarının, kabuklarının veya çiçeklerinin kullanılmasını ifade eder. ${ }^{78}$ Bitkisel tedavi son zamanlarda alternatif tedavi seçenekleri arayan hastalar arasında giderek daha popüler hale gelmiştir. ${ }^{79}$ Bitkiler, vücut yüzeylerinde topikal olarak kullanılan yarı kat1 preparat olan merhem formunda hazırlanarak uygulanır. ${ }^{37}$

Mohammadi ve arkadaşlarının yaptığı çalışmada, epizyotomi onarımı tamamlandıktan 1 saat sonrasında kadınlardan 10 gün süreyle günde iki kez $12 \pm 2$ saat aralıklarla İnsizyon bölgesine yaklaşık $2 \mathrm{~mL}$ cinnamon (tarçın) merhemi sürdükten 1-2 dakika sonra hijyenik kadın bağı takılarak uygulama yapmaları istenmiştir. Plasebo grubuna ise tarçın özü ha- 
riç aynı malzemelerden hazırlanan aynı renk, şekil ve boyutta olan tüplere hazırlanan kremi aynı prosedürde uygulamaları istenmiştir. Çalışma sonucunda tarçın merhemi uygulamasının doğumdan sonraki 10 gün içinde ağrı şiddetini azaltmada etkili olduğu saptanmıştır. ${ }^{37}$ Asgharikhatooni ve arkadaşlarının yaptığı çalışmada, kadınlardan equisetum arvense (at kuyruğu) Merhemi epizyotomi bölgesine sürdükten 1-2 dakika sonra hijyenik kadın bağ 1 takarak günde iki kez $12 \pm 2$ saat aralıklarla 10 gün süreyle uygulama yapmaları istenmiştir, plasebo grubuna ise vazelin ve birkaç damla at kuyruğu ekstresi kullanılarak hazırlanan steril plasebo merhemi girişim grubundaki gibi uygulanmıştır. Çalışma sonucunda at kuyruğu merhemi uygulamasının doğumdan sonraki 10 gün içinde perineal ağrı şiddetini azaltmada etkili olduğu saptanmıştır. ${ }^{38}$ Khadivzade'nin lavanta kreminin epizyotomi ağrısını gidermek için kullandığı bir çalışmada doğumdan sonraki üç, beş ve on günlük günlerdeki ağrı düzeyinin kontrol grubuna kıyasla anlamlı şekilde azaldığı, ilk 24 saatte anlamlı bir azalma olmadığı saptanmıştır. ${ }^{80}$

Papatya kremi, yeşil çay merhemi, Achillea millefolium (Civanperçemi) ve Hypericum perforatum (sar1 kantaron) merhemlerinin, epizyotomi sonrası perineal ağr1 düzeyini azalttığg saptanmıştır. ${ }^{81-83} \mathrm{Hem}$ bal hem de fenitoin kreminin karşılaştırıldığı bir çalışmada, bal uygulamasının yara iyileşmesinde daha etkili olduğu fakat perineal ağrı düzeyi açısından iki girişimin de etkili olmadığ1 saptanmıştır. ${ }^{84}$

\section{SONUÇ VE ÖNERILER}

Nonfarmakolojik ağrı kontrol yöntemlerine ilişkin kanıt düzeyi yüksek çalışmaların sayısı oldukça sınırlıdır. Doğum sonu dönemde, perineal ağrı için tedavi alternatifleri sunmak için bilimsel kanıtlara gereksinim vardir. ${ }^{85}$

Sistematik derlemede, epizyotomi çeşidi olarak çoğunlukla mediolateral yöntem kullanıldığı, yapılan uygulamaların değerlendirilmesinde ilk bir haftalık sürecin etkin olduğu görülmektedir. Epizyotomi uygulamasının primiparlarda daha fazla yapıldığ 1 saptanmıştır. Epizyotomi sonrası perineal ağrının tedavisinde non-farmakolojik yöntemleri ve bu yöntemlerin ağrı üzerindeki etkilerinin incelendiği bu sistematik derlemede; epizyotomi sonrası perineal ağrının giderilmesinde soğuk jel pedi ve buz paketi uygulamasının, düşük frekanslı TENS ve yüksek frekanslı TENS'in, bilek-ayak akapunktur uygulamas1- nın, lavanta-timolü ilave edilerek hazırlanan yıkama solüsyonunun, tarçın merhemi ve atkuyruğu merheminin etkili olduğu, DDLT'nin, kulak akupunktur uygulamasının etkili olmadığı saptanmıştır. Lavanta yağı ile hazırlanan oturma banyosunun bir çalışmada etkili olduğu saptanırken diğer çalışmada etkili olmadığı saptanmıştır.

Ülkemizde epizyotomi uygulaması sonrası, non-farmakolojik yöntemler sinırlı düzeyde kullanılmaktadır. non-farmakolojik yöntemlerin uygulanması aşamasında hekim, hemşire ve sağlık çalışanlarının yöntem kullanımı konusunda temel bilgilere sahip olmaları gerekmektedir. Epizyotomi sonrası perineal ağrının giderilmesinde en etkili yöntemlerin kanıt düzeyinde araştırılması, bu yöntemlerin kullanımı ile ilgili sağlık çalışanlarına danışmanlık yapılması önerilmektedir.

\section{KAYNAKÇA}

1. Yilmaz, S.D., Vural, G., Bodur, S. (2010). "Epizyotomi Bak1mında Serum Fizyolojik ve Rivanolün İyileşme Sürecine Etkisi”. Trakya Üniversitesi Tıp Fak Dergisi, 27 (2), 172-177.

2. Durmaz, A., Buğdayci, R. (2013). "Epizyotomi İyileşmesin Etkileyen Faktörler". Turkish Journal of Public Health, 11 (2), 72-85.

3. Carroli, G., Mignini, L. (2009). "Episiotomy for Vaginal Birth”. Cochrane Database Of Systematic Reviews, 1 (3).
4. Dönmez S., Sevil Ü. (2009). "Rutin Epizyotomi Uygulanmas1nın Gerekliliği”. Maltepe Üniversitesi Hemşirelik Bilim ve Sanatı Dergisi, 2 (3), 105-112.

5. Declercq, E., Cunningham, D. K., Johnson, C., Sakala, C. (2008). "Mothers' reports of postpartum pain associated with vaginal and cesarean deliveries: Results of a national survey". Birth, 35, 16-24. 
6. Macarthur, A. J., Macarthur, C. (2004). "Incidence, severity, and determinants of perineal pain after vaginal delivery: A prospective cohort study". American Journal of Obstetrics and Gynecology, 191, 1199-1204.

7. Sapmaz, E., Altungül, A.Ç. (2012). "Sağ Medyolatera Epizyotomi Vakalarında Ağrı Kesici Olarak Tenoksikam ile Parasetamolün Karşılaştırılması”. Fırat Tıp Dergisi, 17 (2), 76 79.

8. Santos, J.O., Oliveira, S.M.J.V., Nobre, M.R.C., Aranha, A.C.C., Alvarenga, M.B. (2012 a). "A Randomised Clinical Trial of The Effect of Low-Level Laser Therapy for Perineal Pain and Healing after Episiotomy: A Pilot Study". Midwifery, 28, 653-659.

9. Ak, Ö.B. (2013). Vaginal Doğum Yapan Kadınlarda Postpartum Perineal Ağrının Değerlendirilmesi. İstanbul Üniversitesi Sağlık Bilimleri Enstitüsü, Kadın Sağlığı ve Hastalıkları Hemşireliği Anabilim Dalı, Yüksek Lisans Tezi, İstanbul.

10. Özveren, H. (2011). Ağrı Kontrolünde Farmakolojik Olmayan Yöntemler”. Hacettepe Üni. Sağlık Bilimleri Fakültesi Hemșirelik Dergisi, 83-92.

11. Korkut Bayındır, S., Cürük, G. N. (2015). “Türkiye'de Ağrıya Yönelik Tamamlayıcı ve Alternatif Tıp Uygulamaları Konusundaki Hemşirelik Tezlerinin İncelenmesi”. Hemşirelikte Eğitim ve Araştırma Dergisi, 12 (3), 162-169.

12. George, S. (2013). A Comparative Study to Assess The Effectiveness of Sitz Bath Versus Infrared Lamp Therapy on Episiotomy Pain and Wound Healıng Among Postnatal Mothers at Selected Hospital, Bangalore. Dissertation Submitted to the Rajiv Gandhi University of Health Sciences, In Partial Fulfillment of Requirement For The Degree of Master of Science in Nursing, Bangalore

13. Karaçam, Z. (2013). "Sistematik Derleme Metodolojisi: Sistematik Derleme Hazırlamak İçin Bir Rehber”. Dokuz Eylül Üniversitesi Hemşirelik Yüksekokulu Elektronik Dergisi, 6 (1), 26-33.

14. Yusamran, C., Titapant, V., Kongjeera, A. (2007). "Relief Perineal Pain After Perineorrhaphy by Cold Gel Pack Pad: A Randomized Controlled Trial". Thai Journal of Nursing Research, 11 (2), 87-95.

15. Mahishale, A., Chougala, A., Patted, S. (2013). "Effect of Therapeutic Ultrasound and Maternal Cooling Gel Pad for Perineal Pain Following Vaginal Delivery With Episiotomy". J Women's Health Care, 2 (3), 1-4

16. Navvabi, S., Abedian, Z., Steen-Greaves, M. (2009) "Effectivness of Cooling Gel Pads and Ice Packs on Perineal Pain”. Britısh Journal Of Midwifery, 17 (11), 724-729.

17. Martin, J.A., Hamilton, B.E., Osterman, M.J., Driscoll, A.K. Mathews, T.J. (2017). Births: final data for 2015.https://data.worldbank.org/indicator/SP.DYN.TFRT.IN, Erișim tarihi: 19.12.2019.

18. Pitangui, A.C.R., Sousa, L., Gomes, F.A., Ferreira, C.H.J., Nakano, A.M.S. (2012). "High-Frequency Tens in PostEpisiotomy Pain Relief in Primiparous Puerpere: A Randomized, Controlled Trial”. J. Obstet. Gynaecol. Res, 38 (7), 980-987.

19.Zafar, S. (2008). "Comparison of A Single-Knot Versus Three Layered Technique of Perineal Repair After Vaginal Delivery in Women Requiring Episiotomy: A Double Blind Randomized Controlled Trial". Turkish German Gynecol Assoc, 9 (3), 12933.

20. Kartal, B., Özhan, T., Cırık M. (2014). "Primipar Kadınların Epizyotomi Bakımına İlişkin Uygulamaları”. Gümüşhane Üniversitesi Sağlık Bilimleri Dergisi, 3 (4) 1056-1066.
21. Kalis, V., Landsmanova, J., Bednarova, B., Karbanova, J., Laine, K., Rokyta, Z. (2011). "Evaluation of The İncision Angle of Mediolateral Episiotomy at 60 Degrees". International Journal of Gynecology and Obstetrics, 112, 220-224.

22. Rasouli, M., Keramat, A., Khosravi, A., Mohabatpour, Z. (2016). "Prevalence and factors associated with episiotomy in Shahroud City, northeast of Iran". Int J Womens Health Reprod Sci, 4 (3), 125-129.

23. Karbanova, J., Rusavy, Z., Betincova, L., Jansova, M., Necesalova, P., Kalis, V. (2014). "Clinical evaluation of early postpartum pain and healing outcomes after mediolateral versus lateral episiotomy". International Journal of Gynecology \& Obstetrics, 127 (2), 152-156.

24. Karaçam, Z., Eroğlu, K. (2003). "Effects of Episiotomy on Bonding and Mother's Health". Journal of Advanced Nursing, 43 (4), 384-94.

25. Sayiner, F.D., Demirci, N. (2007). "Prenatal Perineal Masajin Vaginal Doğumlarda Etkinliği”". İ̈FN Hemşirelik Dergisi, 15 (60), 146-154.

26. Althabe, F., Belizan, J.M., Bergel, E. (2002). "Episiotomy Rates in Primiparous Women in Latin America: Hospital Based Descriptive Study”. Bjm, 324 (7343), 945-6.

27. Çiftpinar, T., Yörük, P., Dündar, Ö., Tütüncü, L., Müngen, E., Yergök, Y.Z. (2009). "Epizyotomi Onarımı Zamanının Postpartum Kan Belirteçlerine Etkisi”. Trakya Üniversitesi Tıp Fakültesi Dergisi, 26 (3), 203-207.

28. Schoon, P.G. (2001). "Episiotomy: yea or nay". Obstet Gynecol Surv, 56(11), 667-9.

29. Sartore, A., De Seta, F., Maso, G., Pregazzi, R., Grimaldi, E., Guaschino, S. (2004). "The Effects of Mediolateral Episiotomy on Pelvic Floor Function After Vaginal Delivery". Obstet. Gynecol., 103 (4), 669-73.

30. Fodstad, K., Staff, A.C., Laine, K. (2014). "Effect of Different Episiotomy Techniques on Perineal Pain and Sexual Activity 3 Months After Delivery". Int. Urogynecol J., 25,1629-1637.

31. Cöçelli, L.P., Bacaksiz, B.D., Ovayolu, N. (2008). "Ağrı Tedavisinde Hemşirenin Rolü”. Gaziantep Tıp Dergisi, 14, 53-58

32. Leventhal, L.C., de Oliveira, S.M.J.V., Nobre, M.R.C., da Silva, F.M.B. (2011). "Perineal analgesia with an ice pack after spontaneous vaginal birth: a randomized controlled trial". The Journal of Midwifery \& Women's Health, 56 (2), 141-146.

33. Oliveira, S., Silva, F., Riesco, M., Rosario, M., Nobre, M. (2012). "Comparison of Application Times for Ice Packs used to Relieve Perineal Pain after Normal Birth: A Randomised Clinical Trial". Journal Of Clinical Nursing, 21, 3382-3391

34. Pitangui, A.C., Araujo, R.C., Bezerra, M.J., Riberio, C.O., Nakano, A. (2014). "Low and high-frequency TENS in postepisiotomy pain relief: a randomized, double-blind clinical trial". Brazilian Journal of Physical Therapy, 18 (1), 72-78.

35. Sheikhan, F., Jahdi, F., Khoei, E.M., Shamsalizadeh, N., Sheikhan, M., Haghani, H., (2012). "Episiotomy Pain Relief: Use of Lavender Oil Essence in Primiparous Iranian Women”. Complementary Therapies in Clinical Practice, 18 (66-70)

36. Marzouk, T., Barakat, R., Ragab, A., Badria, F., Badawy, A (2015). "Lavender-thymol as a new topical aromatherapy preparation for episiotomy: a randomised clinical trial". Journal of Obstetrics and Gynaecology, 35 (5), 472-475.

37. Mohammadi, A., Mohammad-Alizadeh-Charandabi, S., Mirghafourvand, M., Javadzadeh, Y., Fardiazar, Z., Effati-Daryani, F., (2014). "Effects of Cinnamon on Perineal Pain and Healing of Episiotomy: A Randomized Placebo-Controlled Trial". Journal Of Integrative Medicine, 12 (4), 359-366. 
38. Asgharikhatooni, A., Bani, S., Hasanpoor, S., Alizade, S.M., Javadzadeh, Y. (2015). "The effect of equisetum arvense (horse tail) ointment on wound healing and pain intensity after episiotomy: a randomized placebo-controlled trial". İrenian Red Crescent Medical Journal, 17 (3).

39. Bleakley, C., McDonough, S., \& MacAuley, D. (2004). "The use of ice in the treatment of acute soft-tissue injury: a systematic review of randomized controlled trials". The American journal of sports medicine, 32 (1), 251-261.

40. Steen, M., Briggs, M., King, D. (2006). “Alleviating postnata perineal trauma: To cool or not to cool?". British Journal of Midwifwry, 14 (5), 304-308

41. Hasegawa, J., Leventhal, L. C. (2009). "Pharmacological and non pharmacological treatmente for relief of perineal pain after vaginal delivery”. Einstein (São Paulo), 7 (2), 194-200.

42. Paiva, C.D.S.B., de Oliveria, S.M.J.V., Francisco, A.A., da Silva, R.L., Mendes, E.D.P.B., Steen, M. (2016). "Length of perineal pain relief after ice pack application: A quasi-experimental study". Women and Birth, 29 (2), 117-122.

43. Beleza, A.C.S., Ferreira, C.H.J., Driusso, P., dos Santos, C.B., Nakano, A.M.S. (2017). "Effect of cryotherapy on relief of perineal pain after vaginal childbirth with episiotomy: a randomized and controlled clinical trial". Physiotherapy, 103 (4), 453458.

44. Abedian, Z., Navabi Rigi, S. D., Dadgar, S., Esmaili, H. (2007) "Comparing the Effect of Colling Gel Pads and Ice Pack, after Episiotomy, on the Intensity od Perinal Pain”. The Iranian Journal of Obstetrics, Gynecology and Infertility, 10 (2), 79-86.

45. Steen, M., Marchant, P. (2007). "Ice packs and cooling gel pads versus no localised treatment for relief of perineal pain: a randomised controlled trial". Evidence-Based Midwifery, 5 (1), $16-23$.

46. Lu, Y. Y., Su, M. L., Gau, M. L., Lin, K. C., Au, H. K. (2015) "The efficacy of cold-gel packing for relieving episiotomy pain-a quasi-randomised control trial". Contemporary nurse, 50 (1), 26-35.

47. Jahdi, F., Sheikhan F., Haghani, H. (2010). "The effect of cooling gel pad on the intensity of perineal pain following episiotomy”. Arak Medical University Journal, 13 (3), 76-83

48. Senol, D.K., Aslan, E. (2017). The Effects of Cold Application to the Perineum on Pain Relief After Vaginal Birth. Asian Nursing Research, 11 (4), 276-282.

49. Kömürcü, N., Ergin, A.B., Çalișkan, E., Buckley, S.J., Çalik K.Y., Coker, H., Karabekir, N. (2013). Doğum Ağrısının Kontrolünde Non- Farmakolojik Yöntemler. (İçinde) N. Kömürcü (Ed.). Doğum Ağrısı Ve Yönetimi. İstanbul: Nobel Tıp Kitapevleri, 63-178.

50. Lamina, S., Shmaila, H., Muhammed, S.A. (2008). "Transcutaneous electrical nevre stimulation (TENS) in the symptomatic management of choronic prostatitis/chronic pelvic pain syndrome: a placebo-control randomized trial". İnternational Braz. J. Urol., 34 (6), 708-714.

51. Proctor, M., Farquhar, C., Stones, W., He, L., Zhu, X., Brown, J. (2010). "Transcutaneous Electrical Nerve Stimulation for Primary Dysmenorrhoea". The Cochrane Library. 1

52. Santana, L.S., Gallo, R.B.S., Ferreira, C.H.J., Duarte, G., Quintana, S.M., Marcolin, A.C. (2016). "Transcutaneous electrical nevre stimulation (TENS) reduces pain and postpones the need for pharmacological analgesia during labour: a randomised trial". Journal of Physiotherapy, 62 (1), 29-34.

53. Son, S. J., Kim, H., Seeley, M. K., Feland, J. B., Hopkins, J. T. (2016). "Effects of transcutaneous electrical nerve stimulation on quadriceps function in individuals with experimental knee pain". Scandinavian journal of medicine \& science in sports, 26 (9), 1080-1090.
54. Cherian, J. J., Harrison, P. E., Benjamin, S. A., Bhave, A. Harwin, S. F., Mont, M. A. (2016). "Do the effects of transcutaneous electrical nerve stimulation on knee osteoarthritis pain and function last?". The journal of knee surgery, 29 (06), $497-$ 501 .

55. Buko, H. S.. (2013). Servikal Disk Hernisine Bağlı Akut Boyun Ağrısında Düşük Doz Lazer Tedavisinin Etkinliği. Tıp Fakültesi Fiziksel Tıp ve Rehabilitasyon Anabilim Dalı, Tıpta Uzmanlık Tezi, Çukurova Üniversitesi, Adana.

56. Doğan, G.E., Demir, T., Orbak, R., (2014). "Periodontolojide Düșük Doz Lazer Uygulamaları". Marmara Üniversitesi Sağlık Bilimleri Enstitüsü Dergisi, 4 (1), 43-50.

57. Burcu, B.A.Ş., Duran, H. (2012). “Temporomandibular Eklem Bozukluklarının Tedavisinde Düşük Doz Lazer Uygulamasının Yeri”. Ondokuz Mayıs Üniversitesi Diş Hekimliği Fakültesi Dergisi, 13 (1).

58. Santos, J.O., Oliveira, S.M.J.V., Silva, F.M.D., Nobre, M.R.C., Osava, R.H., Riesco, M.L.G., (2012 b). "Low-Level Laser Therapy for Pain Relief After Episiotomy: A Double-Blind Randomised Clinical Trial". Journal Of Clinical Nursing, 21(35133522).

59. Alvarenga, M.B., de Oliveria, S.M.J.V., Francisco, A.A., da Silva, F.M.B., Sousa, M., Nobre, M.R. (2017). "Effect of lowlevel laser therapy on pain and perinal healing after episiotomy: A triple-blind randomized controlled trial". Lasers in surgery and medicine, 49 (2), 181-188.

60. Al-Shaikh, S. F. (2011). "The Evaluation of Low Level Laser Therapy Using the Diode Laser in Enhancement of Episiotomy Wound Healing”. Medical Journal of Babylon, 8 (2), 213-220.

61. Enwemeka, C.S., Parker, J.C., Dowdy, D.S., Harkness, E.E., Harkness, L.E., Woodruff, L.D. (2004). "The efficacy of lowpower lasers in tissue repair and pain control: a meta-analysis study". Photomedicine and Laser Therapy, 22 (4), 323-329.

62. Bjordal, J.M., Johnson, M.I., Iversen, V., Aimbire, F., LopesMartins, R.A.B. (2006). "Low-level laser therapy in acute pain: a systematic review of possible mechanisms of action and clinical effects in randomized placebo-controlled trials". Photomedicine and Laser Therapy, 24 (2), 158-168.

63. Chow, R.T., Johnson, M.I., Lopes-Martins, R.A., Bjordal, J.M. (2009). "Efficacy of low-level laser therapy in the management of neck pain: a systematic review and meta-analysis of randomised placebo or active-treatment controlled trials". The Lancet, 374 (9705), 1897-1908.

64. Kelly, R.B. (2009). "Acupuncture for pain". American family physician, 80 (5)

65. Yilar, Z. (2014). Ayak Refleksolojisinin Doğum Ağrısına ve Doğum Eyleminin Süresine Etkisi. Atatürk Üniversitesi Sağlık Bilimleri Enstitüsü, Doğum, Kadın Sağlığı ve Hastalıkları Hemşireliği Anabilim Dalı, Doktora Tezi, Erzurum.

66. Skilnand, E., Fossen, D., Heiberg, E. (2002). “Acupuncture in the management of pain in labor". Acta obstetricia et gynecologica Scandinavica, 81 (10), 943-948.

67. Kindberg, S., Klünder, L., Strom, J., Henriksen, T. B., (2009). "Ear Acupuncture or Local Anaesthetics as Pain Relief During Postpartum Surgical Repair: A Randomized Controlled Trial". Bjog: An International Journal Of Obstetrics \& Gynaecology, 116 (4), 569-576.

68. Marra, C., Pozzi, I., Ceppi, L., Sicuri, M., Veneziano, F., Regalia A.L. (2011). "Wrist-Ankle Acupuncture as Perineal Pain Relief After Mediolateral Episiotomy:A Pilot Study". The Journal Of Alternative And Complementary Medicine, 17 (3), 239-241.

69. Usichenko, T.I., Dinse, M., Hermsen, M., Witstruck, T., Pavlovic, D., Lehmann, C. (2005). "Auricular acupuncture for pain relief after total hip arthroplasty-a randomized controlled study”. Pain, 114 (3), 320-327. 
70. Chen, Y., Tian, S., Tian, J., Shu, S. (2017). "Wrist-ankle acupuncture (WAA) for primary dysmenorrhea (PD) of young females: study protocol for a randomized controlled trial". BMC complementary and alternative medicine, 17 (1), 421.

71. Zhu, L.B., Chan, W.C., Lo, K.C., Yum, T.P., Li, L. (2014) "Wrist-ankle acupuncture fort he treatment of pain symptoms: a systematic review and meta-analysis". Evidence-Based Complementary and Medicine, 2014

72. Sar, S., Kahya, E., Ataç, A. (2011). "History of Aromatherapy and Some Examples of Medicinal Plants Used in This AreaAromaterapinin Tarihçesi ve Bu Alanda Kullanılan Tıbbi Bitkilerden Örnekler". Mersin Üniversitesi Tıp Fakültesi Lokman Hekim Tıp Tarihi ve Folklorik Tıp Dergisi, 32-33.

73. Bingöl, F.N., Akbulut, G., (2012). "Tip 2 Diabetes Mellitus Ve Tarçın”. Bozok Tıp Dergisi, 3 (39-46).

74. Vakilian, K., Atarha, M., Bekhradi, R., Chaman, R. (2011). "Healing advantages of lavender essential oil during episiotomy recovery: a clinical trial". Complementary therapies in clinical practice, 17 (1), 50-53.

75. Olapour, A., Behaeen, K., Akhondzahed, R., Soltani, F., al Sadat Razavi, F., Bekhradi, R. (2013). "The effect of inhalation of aromatherapy blend containing lavender essential oil on cesarean postoperative pain". Anesthesiology and pain medicine, 3 (1), 203

76. Karabulut, H. (2014). Doğum Eyleminde Aromaterapinin Etkileri. Sağlık Bilimleri Enstitüsü Kadın Sağlığı Ve Hastalıkları Hemşireliği Anabilim Dalı, Yüksek Lisans Tezi, T.C. İstanbul Üniversitesi, İstanbul

77. Masoumi, Z., Keramat, A., Hajiaghaee, R. (2011). "Systematic review on effect of herbal medicine on pain after perineal episiotomy and cesarean cutting". Journal of Medicinal Plants, 10 (40), 1-16.
78. Chhretri, H.P., Yogol, N.S., Sherchan, J., Anupa, K.C., Mansoor, S., Thapa, P. (2010). "Formulation and evaluation of antimicrobial herbal ointment". Kathmandu University Journal of Science, Engineering and Technology, 6 (1), 102-107.

79. Bedi, M.K., Shenefelt, P.D. (2002). "Herbal therapy in dermatology". Archives of dermatology, 138 (2), 232-242.

80. Khadivzadeh, T., Molkizadeh, M., Rakhshandeh, M. (2009). "P302 Evaluation of lavander cream effect on episiotomy pain and wound healing in primiparous women." International Journal of Gynecology \& Obstetrics, 107 (S2).

81. Aradmehr, M., Azhari, S., Ahmadi, S., Azmoude, E. (2017) "The effect of chamomile cream on episiotomy pain primiparous women: a randomized clinical trial". Journal of caring sciences, 6 (1), 19

82. Shahrahmani, H., Kariman, N., Jannesari, S., Rafieian-Kopaei, M., Mirzaei, M., Ghalandari, S., Mardani, G. (2018). "The effect of gren tea ointment on episiotomy pain and wound healing in primiparous women: A randomized, double-blind, placebocontrolled clinical trial". Phytotherapy Research, 32 (3), 522530.

83. Hajhashemi, M., Ghanbari, Z., Movahedi, M., Rafieian, M., Keivani, A., Haghollahi, F. (2018). "The effect of Achillea millefolium and Hypericum perforatum ointments on episiotomy wound healing in primiparous women". The Journal of Maternal-Fetal \& Neonatal Medicine, 31 (1), 63-69.

84. Lavaf, M., Simbar, M., Mojab, F., Majd, H.A., Samimi, M. (2017). Comparison of honey and phenytoin (PHT) cream effects on intensity of pain and episiotomy wound healing in nulliparous women. Journal of Complementary and Integrative Medicine, 15(1)

85. Hasegawa, J., Leventhal, L.C., (2009). "Pharmacological and Non-Pharmacological Treatment for Relief of Perineal Pain after Vaginal Delivery”. Einstein (São Paulo), 7 (2), 194-200. 